\title{
Trouble in paradise: How women's intra-household bargaining power affects marital stability
}

\author{
M.V. Dayanti \& T. Dartanto \\ Department of Economics, Faculty of Economics and Business, Universitas Indonesia, Depok, Indonesia
}

\begin{abstract}
The substantial improvement in socio-economic conditions in Indonesia has been followed by an increase in women's independence and empowerment as well as the divorce rate. This study aims at examining the relationship between women's bargaining power and marital stability. According to Nash Equilibrium derived from mixed strategy, the relationship between women's bargaining power and marital stability could be both positive and negative depending on the level of women's bargaining power. We conducted an online survey among 752 married women to find out who acted as decision maker on their household expenditure, which indicated women's bargaining power, and to identify occurrence of households conflict which indicated stability. By controlling such variables as education, income, ethnicity, religion and divorce experience, our econometric estimations confirm the U-shaped relationship between women's bargaining power and stability. As the women's bargaining power increases, household conflict decreases until it reaches some level beyond which the conflict starts to increase. Marital instability tends to be higher when the wives have experienced divorce, are in mixed unions, and were married because of other possible reasons (marriage by accident). This study suggests that a smaller socio-economic gap between couples will guarantee less household conflict and more stability in marriages.
\end{abstract}

\section{INTRODUCTION}

Socio-economic conditions in Indonesia have been improving rapidly in the past three decades. The World Bank reported that the per capita GDP (constant, 2010 US\$) of Indonesia had jumped from $\$ 1,095$ (1980) to $\$ 3,834$ (2015), while in terms of women's empowerment, gender parity index for gross enrolment ratio in tertiary education had substantially increased from 0.465 (1982) to 1.11 (2013). Latest figures indicate that women in Indonesia have become more empowered and independent. However, some improvements in women's empowerment have resulted in numerous adverse impacts on marital stability; hence the rise of divorce rate. BBC (2009) reported that the divorce rate had spiked from an average of 20,000 cases a year to more than 200,000 a year during 1999-2009. Women were the main driver behind this phenomenon. Their economic independence and greater awareness of their rights would be some of the reasons for divorce. Arijaya (2011) elaborated on the reason behind a sharp increase in divorce rate. Of all the factors, nearly $40 \%$ of couples were divorced due to disharmonious marriage factors; one of them was the prolonged spousal dispute. Women have started to understand that they have a right to terminate the marriage too. The large number of divorce cases is initiated by women $-57 \%$ of divorce cases compared to only $28 \%$ that were filed by men. Women's growing independence is the culprit of this unfortunate issue. This research then aims at elaborating the relationship between women's bargaining power and marital stability.

In the realm of Indonesia patriarchal society, Indonesian women have long struggled in obtaining greater involvement in the nation's development and in getting their voices heard. The increasing exposure to equal opportunities of men and women could be indicated, to a lesser extent, by the rise of women's employment and educational attainment. Schaner and Das (2016) have reported that there is evidence of increasing participation of younger women living in the urban areas in wage employment. The study also found a narrowing trend in gen- 
der gap in wage employment - in 2011, the median women earned $84 \%$ as much as their male counterparts compared to $57 \%$ in 1990 . In 2011 , almost $30 \%$ of women obtained senior secondary and post-secondary degrees compared to merely $11 \%$ of women in 1990 and around $8 \%$ of women had tertiary degree (Schaner \& Das, 2016). Consequently, greater participation in wage employment has enabled them to be more economically independent, while better access to education has enriched them with better understanding of their worth.

The surging divorce rate and the increasing women's independence-hence, their bargaining power-have awakened interests in the causes of marital dissolution. Past empirical studies have tried to explain that the impact of women's increasing bargaining power may increase marital instability. Yet the results are mixed. Booth et al. (1984), Hiedemann et al. (1998), and Winslow (2011) found a positive correlation between wives' economic independence and the likelihood of marital dissolution. Meanwhile, Weagley et al. (2007) suggest that the decrease in wives' housework time increased the odds of divorce. Furthermore, Ono (1998) proved that the relationship between the wife's bargaining power and the risk of dissolution followed the U-shaped curve. Risman and Johnson-Summerford (1998) confirm that the risk of divorce reached the lowest point in egalitarian unions. On the other hand, Heckert et al. (1998) and Rogers (2004) found the exact opposite result, arguing that the association between wives' bargaining power as depicted by their economic resources and the likelihood of marital dissolution formed an inverted U-shaped curve.

Due to inconclusive previous evidence, as well as very little evidence/empirical studies examining Indonesia's case, we attempt to investigate the relationship between women's bargaining power within family and marital stability. However, instead of using women's economic resources as the proxy of women's bargaining power, we define bargaining power as the person who has the authority to control expenditure in family decision-making. This definition follows Agarwal (1997) that relative intra-household bargaining power could be defined as the person who participates in household decision-making processes. Furthermore, instead of using divorce rate as the proxy of instability, this study uses ten-item questions of Marital Instability Index. We apply both game-theoretic and econometric models to theoretically and empirically provide clear evidence of the relationship between women's bargaining power and marital stability. This study will then contribute to the growing literature on household economics as well as providing valuable information on how to prevent marital dissolution, especially in Indonesia.

\section{THEORETICAL MODEL AND EMPIRICAL SPECIFICATION}

\subsection{The spousal bargaining game}

This study establishes a simple game-theoretic model to analyse the relationship between women's relative intra-household bargaining power and marital stability. The spousal bargaining game consists of two rational players, the wife and the husband. The strategy of the wife is to decide whether to actively participate in the household decision-making process or to obey her husband. The strategy of the husband is also to decide whether to actively participate in the household decision-making process or to obey his wife. The idea of the spousal bargaining game follows Dartanto's (2010) work on corruption game.

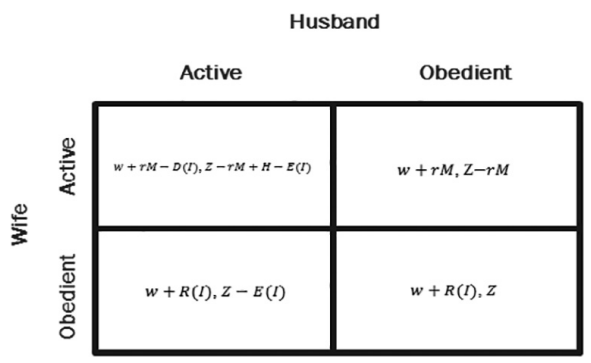

Source: Authors. 
To start, let $w$ be the wife's benefit for being married, $r$ is the fraction/percentage of the wife's participation in household decision-making, $M$ is a value of marital conflict which can be measured using the value of wife's hypothetical situation outside marriage, such as the wife's expected income, career opportunity, and inheritance benefits. The higher value of marital conflict borne by the wife will increase the attractiveness of dissolution. $D(I)$ is the cost borne by the wife when both spouses actively participate in household decisionmaking. $R(I)$ is the reward received by the wife when she obeys her husband's decisions, such as the husband's extra love, or the husband being extra nice. Hence, the benefits from relatively higher women's bargaining power if her husband is obedient are the sum of the wife's benefits for being married and the gain from being active; hence, $w+r M$. On the contrary, the benefits if both players jointly participate in the household decision-making process are the sum of the wife's benefits for being married and the gain from her increase in bargaining power minus the costs inflicted, $(w+r M-D(I))$. Furthermore, the benefits to the wife for being obedient to her husband are the sum of her benefits of being married and the reward she receives for being obedient $(w+R(I))$. The condition that is considered acceptable for the wife's participation in household decision-making is when the gain from her higher bargaining power is greater than the reward she receives for being obedient, $r M>R(I)$. Under those conditions, the wife's active participation in household decision-making is economically rational.

Let us assume that $D$ is a continuous increasing function of the women's bargaining power index $(I), \frac{\partial D(\mathrm{I})}{\partial I}=D^{\prime}(I)>0$. This suggests that the costs paid by the wife, in a household with higher women's relative intra-household bargaining power compared to their husbands, are larger than that of households with relatively lower women's intra-household bargaining power. Hereafter, we assume that the second derivative of $D(I)$ is negative, $\frac{\partial^{2} D(I)}{\partial I^{2}}=D^{\prime \prime}(I)<0$. On the other hand, $R(I)$ is a continuous decreasing function in $I, \frac{\partial R(I)}{\partial I}=\stackrel{\partial I^{2}}{R^{\prime}}(I)<0$. These assumptions imply that in a household with relatively lower women's intra-household bargaining power will receive better reward from their husbands.

On the husband's side, $Z$ is the utility from his domination, $H$ represents the husband's pride, and $E(I)$ is the cost of enforcement paid by the husband as a function of the women's bargaining power. If the husband performs an active participation in household decisionmaking as does his wife, he will get benefits of $Z-r M+H-E(I)$. We assume that the benefit received from the husband's domination is larger than the cost of enforcement, $Z>$ $E(I)$. Accordingly, the husband's active participation in household decision-making is economically rational. Let $E$ be a continuous increasing function in $I, \frac{\partial E(I)}{\partial I}=E^{\prime}(I)>0$ and the negative second derivative, $\frac{\partial^{2} E(I)}{\partial I^{2}}=E^{\prime \prime}(I)<0$. The high value of $I$ represents more cost of enforcement needed for negotiating with his partner.

The Nash Equilibrium derives from assumptions $r M-D(I)<R(I)$ and $r M<Z$. The first assumption means that the net benefits of actively participating in household decision-making when their husbands are also active decision makers are smaller than the net benefits for being obedient. It suggests that the wife will choose to actively participate in household decision-making if the net benefits of being active are larger than that of being obedient. The second assumption means that the value of the husband's domination is greater or equal to the gain for a wife's higher bargaining power. If these assumptions are violated, there is no rational reason for the husband's active participation in the household decision-making process.

In this bargaining game, a mixed strategy for the husband is the distribution function $(p, 1-p)$, where $p$ is the probability for being actively participative in the household decisionmaking process and $1-p$ is the probability for being obedient to his wife, for $0 \leq p \leq 1$. A mixed strategy for the wife is the distribution function $(q, 1-q)$, where $q$ is the probability for being actively participative in decision-making and $l-q$ is the probability for being obedient, for $0 \leq q \leq 1$. From these explanations, the solution of $p$ can be derived by following the expected benefits of the wife as shown below:

$$
\begin{aligned}
E\left(\pi_{\text {active }}\right) & =p(w+r M-D(I))+(1-p)(w+r M) \\
& =-p D(I)+(w+r M)
\end{aligned}
$$




$$
\begin{aligned}
E\left(\pi_{\text {obedient }}\right) & =p(w+R(I))+(1-p)(w+R(I)) \\
& =w+R(I)
\end{aligned}
$$

By substituting Equation 2 into Equation 1, we obtain:

$$
p=\frac{r M-R(I)}{D(I)}
$$

or,

$$
M=\frac{p D(I)+R(I)}{r}
$$

From Equation 3, it can be inferred that an increase in the gain of a wife's higher bargaining power $(r M)$ is also an increase in the probability of a husband's participation in the household decision-making processes. The husband's active participation in household decisionmaking is needed to lessen the wife's dominance or active participation. Thus, the higher the costs endured by the wife and the higher the reward she receives, the lower the probability of the husband's active participation. Equation 4 implies that the husband's active participation will increase the rate of marital conflict because it deters the wife's preferences in household decision-making. The higher cost of the wife's bargaining power and higher reward received by the wife for being obedient also increases the value of marital conflict $(M)$.

Based on Equation 4, we can derive the impact of women's bargaining power from conflict. The first order condition of Equation 4 is expressed below:

$$
M^{\prime}=\frac{p D^{\prime}(I)+R^{\prime}(I)}{r} .
$$

According to the first order condition depicted in Equation 5, the value of $M^{\prime}$ will depend on the level of women's bargaining power, that is $I$. If we assume that $D^{\prime}(I)>0$ and $R^{\prime}(I)<0$, the value of $M^{\prime}$ can be both negative and positive depending on $I$. If $p D^{\prime}(I)$ $>R^{\prime}(I)$ then $M^{\prime}$ will be positive and if $p D^{\prime}(I)<R^{\prime}(I)$ then $M^{\prime}$ will be negative. $M^{\prime}$ will be zero if $p D^{\prime}(I)=R^{\prime}(I)$. Such condition is considered as the turning point. Indeed, the relationship between marital conflict and women's bargaining power will be a positive one, which means higher bargaining power will increase the rate of marital conflict when the reward she receives from her husband cannot outweigh the increase in costs she endures. Yet, the relationship will be negative which means that higher women's bargaining power will reduce the rate of marital conflict when the reward she receives exceeds the cost of higher bargaining power.

\subsection{Model specification}

The data used in this research is obtained through online survey by spreading a four-part questionnaire. The subject is limited to only married women. This study adapts the list of questions from IFLS Book 3A Section Pengambilan Keputusan (Decision-Making) as the proxy for women's bargaining power and questions from Marital Instability Index as the proxy for instability. The section Pengambilan Keputusan consists of a list of questions of couples' participation in the household decision-making process, and the Marital Instability Index consists of a list of questions that measure the tendency to terminate the marriage. This research tested four models to investigate the relationship between women's participation in intra-household decision-making and the occurrence of intra-household conflict. Each of these models was demonstrated in the following form:

$$
\text { Conflict }=\beta_{0}+\beta_{1} \text { BPower }+\beta_{2} \text { BPowerS } Q+\beta_{3} \text { ControlVar }+\epsilon
$$




\section{RESULTS AND ANALYSIS}

Based on the regression results, the coefficient of BPower is negative in value, but the coefficient of BPowerSQ is positive. This indicates the existence of a non-linear relationship between those two, that is that women's bargaining power negatively impacts the marital instability while its squared shifts in the opposite direction. Women's higher bargaining power does not solely encourage or discourage the household's marital stability. Yet, both effects may prevail at the same time depending on the degree of women's bargaining power. Both the coefficient of BPower and BPowerSQ prove the theoretical prediction made in the spousal bargaining game that higher women's bargaining power can only increase stability up to a certain point. Surpassing this point implies that higher women's bargaining power imposes a threat to marriage stability. Table 1 below shows the regression results.

\subsection{Regression results}

Following the U-shaped curve (Figure 1), in households where the wives have a relatively lower or higher bargaining power than their husbands, the instability is higher compared to those where both spouses have nearly equal bargaining power. The graph presents a simple illustration that the increasing women's bargaining power could alleviate the instability within the family up to a certain point. At this state, the intra-family conflict arises due to the wife's true

Table 1. The regression results.

\begin{tabular}{|c|c|c|c|c|}
\hline & $\begin{array}{l}\text { Model } 1 \\
\text { conflict } \\
\text { index }\end{array}$ & $\begin{array}{l}\text { Model } 2 \\
\text { conflict } \\
\text { index }\end{array}$ & $\begin{array}{l}\text { Model } 3 \\
\text { conflict } \\
\text { index }\end{array}$ & $\begin{array}{l}\text { Model } 4 \\
\text { conflict } \\
\text { index }\end{array}$ \\
\hline Bargaining Power & $\begin{array}{l}-1.539 * * * \\
(0.311)\end{array}$ & $\begin{array}{l}-1.444 * * * \\
(0.312)\end{array}$ & $\begin{array}{l}-1.263^{* * *} \\
(0.308)\end{array}$ & $\begin{array}{l}-1.140 * * * \\
(0.307)\end{array}$ \\
\hline Squared Bargaining Power & $\begin{array}{l}0.288^{* * *} \\
(0.051)\end{array}$ & $\begin{array}{l}0.271 * * * \\
(0.051)\end{array}$ & $\begin{array}{l}0.238^{* * *} \\
(0.05)\end{array}$ & $\begin{array}{l}0.217 * * * \\
(0.05)\end{array}$ \\
\hline Wife's Education ( 1 = higher than husband) & & $\begin{array}{l}0.040^{*} \\
(0.023)\end{array}$ & $\begin{array}{l}0.031 \\
(0.022)\end{array}$ & $\begin{array}{l}0.033 \\
(0.022)\end{array}$ \\
\hline Wife's Income ( 1 = higher than husband) & & $\begin{array}{l}0.055^{*} \\
(0.029)\end{array}$ & $\begin{array}{l}0.047^{*} \\
(0.028)\end{array}$ & $\begin{array}{l}0.036 \\
(0.028)\end{array}$ \\
\hline Ethnicity (1 = different) & & & $\begin{array}{l}0.026 \\
(0.019)\end{array}$ & $\begin{array}{l}0.028 \\
(0.019)\end{array}$ \\
\hline Religion (1 = different) & & & $\begin{array}{l}0.105^{*} \\
(0.0608)\end{array}$ & $\begin{array}{l}0.101^{*} \\
(0.0604)\end{array}$ \\
\hline Parental divorce ( 1 = divorced $)$ & & & $\begin{array}{l}0.0679 * \\
(0.0373)\end{array}$ & $\begin{array}{l}0.0657^{*} \\
(0.037)\end{array}$ \\
\hline Divorce experience $(1$ = divorced $)$ & & & $\begin{array}{l}0.266^{* * *} \\
(0.046)\end{array}$ & $\begin{array}{l}0.254^{* * * *} \\
-0.046\end{array}$ \\
\hline Taaruf (1 = taaruf $)$ & & & & $\begin{array}{l}-0.055 \\
(0.035)\end{array}$ \\
\hline Arranged Marriage $(1=$ arranged marriage $)$ & & & & $\begin{array}{l}0.046 \\
(0.068)\end{array}$ \\
\hline Others $(1=$ others $)$ & & & & $\begin{array}{l}0.211 * * * \\
(0.062)\end{array}$ \\
\hline Observations & 752 & 752 & 752 & 752 \\
\hline R-squared & 0.112 & 0.121 & 0.173 & 0.189 \\
\hline $\begin{array}{l}\text { F-stat } \\
\text { Standard errors in parentheses }\end{array}$ & 47.3 & 25.69 & 19.43 & 15.71 \\
\hline
\end{tabular}

*significant at 10\%; ** significant at 5\%; ***significant at $1 \%$. 
interest, which in part suggests her well-being is not fully perceived in the household decision-making processes. Hence, the husbands' interests mostly dominate the household's utility. According to Agarwal's (1997) definition of bargaining power, which is the person who participates in the decision-making processes and determines what decisions to make, the relatively low women's bargaining power implies low participation in the household decision-making processes. Women are not keen to urge hard bargains with their husbands and therefore cannot get more than they would (England \& Killbourne (1994) in Pollak). This less-perceived wellbeing in household decision-making processes can incite conflict among spouses.

However, as a woman's bargaining power starts to increase, the household moves to reach stability, that is, the higher the woman's intra-household bargaining power, the less the occurrence of intra-family conflict. The increase of women's bargaining power means that they have more involvement in household decision-making processes. They are getting more involved in determining the allocation of household expenditure together with their spouses. As a consequence, their active participation in household decision-making processes drives down the intra-family conflict because their true interests and preferences are embedded in the household's joint decisions. Another reason as to why marital instability and women's bargaining power move in the opposite direction before surpassing the turning point is that the husbands are willing to give more reward to their wives in order to keep them obedient. As long as the reward that the wife receives outweighs both the costs inflicted from higher bargaining power and the husband's active participation in household decision-making processes, the marital instability will go down.

Yet, beyond the conflict-minimising point, the increasing women's bargaining power, ironically, hampers the household's stability. It occurs when their bargaining power is relatively higher than their spouses, resulting in increasing spousal conflict. The relatively higher women's bargaining power means that they are prone to dictate the decisions made within the family or, at an extreme level, dominate the decisions made in the household. Indeed, this will hurt the husbands' domination as well as their pride.

The U-shaped curve form indicates that the degree of marital conflict will attain the lowest point when the women's intra-household bargaining power index ranges from 2.62-2.67. This point is considered the turning point. This turning point implies that the wife participates in at least five areas of decision-making in the household. This compelling evidence emphasises an important conclusion: when women's bargaining power is relatively too low and too high compared to their spouses it imposes a threat to marriage stability. It is only a matter of bargaining power level that becomes the determining factor to attain the stability. The wives can alleviate marital conflict by increasing participation in household decisionmaking process in allocating resources to achieve higher family welfare. However, when this optimum level is surpassed, the increasing women's bargaining power becomes hazardous as it raises the marital instability.

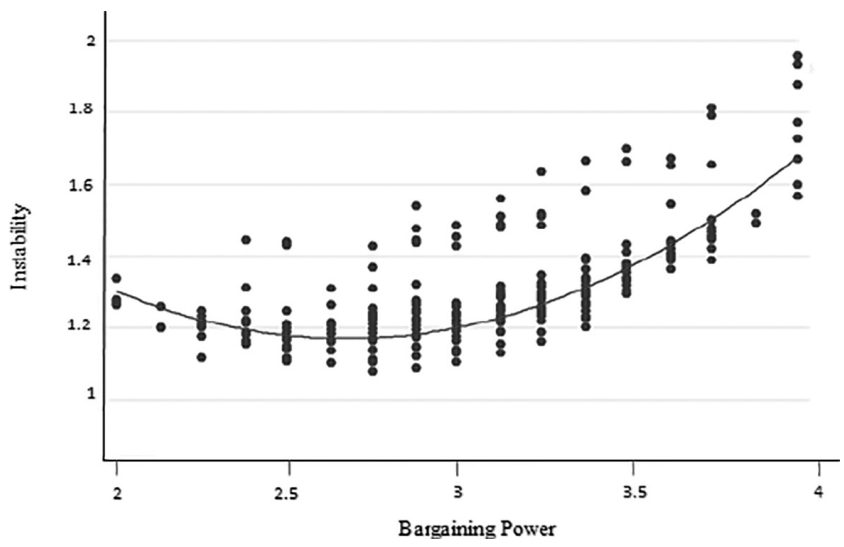

Figure 1. The Relationship between instability and bargaining power.

Source: Author's calculation. 
The regression result suggests that wives who are 'marrying down' suffer relatively higher marital instability compared to those whose educational attainment is lower or equal to their husbands, ceteris paribus. This suggests the importance of assortative mating as spouses with equal level of income and education result in lower instability. The mixed unions-spouses with different religious beliefs or ethnicity — suffer relatively higher marital instability, ceteris paribus. Past studies suggested that spousal dissimilarity in religious beliefs and ethnicity elevated the risk of dissolution (Lehrer \& Chiswick, 1993; Vaaler et al., 2009; Clarkwest, 2007).

Another substantive finding is that the wives' experience of parental divorce can elevate the occurrence of spousal conflict, ceteris paribus, though not statistically significant. As compelling as parental divorce suggests, the wives' divorce experiences also suffer from higher proneness to conflict in remarriages, ceteris paribus. According to several studies, children of divorce are more likely to end up in divorce compared to those from intact families. They are more likely to experience lower marital quality, lower marital commitment and confidence, and have a higher tendency to end up in divorce (Glenn \& Kramer, 1987; Whitton et al., 2008). An individual's divorce experience also contributes to the high probability of instability within remarriage. Becker (1981) gave a plausible explanation concerning this issue. $\mathrm{He}$ argued that remarried individuals were inclined to have characteristics that diminished the gain from marriage compared to those in first marriages.

Last, the regression result poses an interesting finding on the importance of choosing our potential partner. Marriages that were united by the so-called taaruf, which is the Islamic-based marriage arrangement, result in lower marital conflict compared to those whose marriages are based on personal choice, ceteris paribus. Some plausible reasons that explain why religion-based marriage arrangement can lower the risk of dissolution are because it enhances the spouse's moral values that could lead to higher fidelity within marriages, encourages the bond between spouses and God which discourages any actions which would displease God, and increases marital quality as they believe that marriages are sacred in the eye of God (Dollahite \& Lambert, 2007). However, family-based arranged marriages (e.g. marriage arranged by the parents) and other possible reasons (e.g. marriage by accident) endure higher instability compared to those whose marriages are based on personal choice, ceteris paribus. Traditionally, parents took a major role in marrying their children off. Yet, from the early 1900s, there has been a substantial change regarding the nature of marriage as an institution due to government regulation and some social movements, such as the legislation on minimum age of marriage, the abolishment of polygamy, and the rise in the importance of female education (Hull, 2006). As a matter of fact, the growing independence generated from those changes has offered more freedom for children to seek their partners based on mutual interests such as love, compatibility, and other romantic attractions. These brief explanations can be used as a rational argument on how arranged marriages have resulted in higher intra-family conflict because, nowadays, the freedom of choice has been an important factor in determining one's well-being.

\section{CONCLUDING REMARKS}

The promising trend of greater participation of women in wage employment and the narrowing trend of gender discrepancy in education between men and women are considered to have precarious effects on marriage stability. However, several past studies focusing on this issue found contradicting results - a positive correlation, a U-shaped curve, and an inverted U-shaped curve. Departing from these mixed results, this study employs a game-theoretic model which later will be proven by econometric estimation to analyse the relationship between women's bargaining power and marital stability.

Based on the spousal bargaining game, marital stability can be positive or negative, depending on the level of women's bargaining power. This non-linear relationship suggests that there exists an optimum level of bargaining power which will minimise instability. Consequently, there should be an incentive to make a joint agreement between interacting parties to achieve an optimum level of women's bargaining power in order to maintain long run stability. The econometric estimation also reveals that the difference in spouses' socio-economic status- 
differences in religion and ethnicity, as well as where the wives earn more and have a higher education than their counterparts - leads to higher instability. Thus, it can be inferred that when the spouses have equal socio-economic status, the marriages are likely to be more stable.

\section{ACKNOWLEDGEMENTS}

The author wishes to thank Dr Teguh Dartanto for his expert advice and also to the anonymous reviewer(s) for their useful suggestions. This research is supported by Publikasi International Terindeks untuk Tugas Akhir Mahasiswa (PITTA) grant from Universitas Indonesia.

\section{REFERENCES}

Agarwal, B. (1997). 'Bargaining' and gender relations: Within and beyond the household. Feminist Economics, $3(1), 1-51$.

Arijaya, R. (2011). Why is divorce in Indonesia increasing? The Jakarta Post. http://www.thejakartapost. com/news/2011/09/12/why-divorce-indonesia-increasing.html\#sthash.IIm45McH.dpuf.

BBC. (2009). Indonesian divorce rate surges. BBC. http://news.bbc.co.uk/2/hi/asia-pacific/7869813.stm.

Becker, S.G. (1981). A treatise on the family. Cambridge, MA: Harvard University Press.

Booth, A., Johnson, D.R., White L. \& Edwards, J.N. (1984). Women, outside employment, and marital instability. American Journal of Sociology, 90(3), 567-583.

Clarkwest, A. (2007). Spousal dissimilarity, race, and marital dissolution. Journal of Marriage and Family, 69(3), 639-653. doi:10.1111/j.1741-3737.2007.00397.x.

Dartanto, T. (2010). The relationship between corruption and public investment at the municipalities' level in Indonesia. Munich Personal RePEC Archive.

Dollahite, D.C. \& Lambert, N.M. (2007). Forsaking all others: How religious involvement promotes marital fidelity in Christian, Jewish, and Muslim couples. Review of Religious Research, 290-307. http://www. jstor.org/stable/20447445.

Glenn, N.D. \& Kramer, K.B. (1987). The marriages and divorces of the children of divorce. Journal of Marriage and Family, 49(4), 811-825. doi:10.2307/351974.

Heckert, D.A., Nowak, T.C. \& Snyder, K.A. (1998). The impact of husbands' and wives' relative earnings on marital disruption. Journal of Marriage and the Family, 60(33815), 690-703. doi:10.2307/353538.

Hiedemann, B., Suhomlinova, O. \& O'Rand, A.M. (1998). Economic independence, economic status, and empty nest in midlife marital disruption. Journal of Marriage and Family, 219-231.

Hull, T.H. (2006). The marriage revolution in Asia. Population Association of America.

Lehrer, E.L. \& Chiswick, C.U. (1993). Religion as a determinant of marital stability. Demography, 30(3), 385-404.

Ono, H. (1998). Husbands' and wives' resources and marital dissolution. Journal of Marriage and the Family, 60(3), 674-689. doi:10.2307/353537.

Pollak, R.S. (1994). For better or worse: The roles of power in models of distribution within marriage. The American Economic Review, 84(2) 148-152.

RAND. Indonesian Family Life Survey (IFLS). Available: http://www.rand.org/labor/FLS/IFLS.html

Risman, B.J. \& Johnson-Sumerford, D. (1998). Doing it fairly: A study of postgender marriages. Journal of Marriage and the Family, 60(1), 23-40. doi:10.2307/353439.

Rogers, S.J. (2004). Dollars, dependency, and divorce: Four perspectives on the role of wives' income. Journal of Marriage and Family, 66(1), 59. doi:10.1111/j.1741-3737.2004.00005.x.

Schaner, S. \& Das, S. (2016). Female labor force participation in Asia: Indonesia country study. $A D B$ Economics Working Paper Series.

Vaaler, M.L., Ellison, C.G. \& Powers, D.A. (2009). Religious influences on the risk of marital dissolution. Journal of Marriage and Family, 71(4), 917-934. doi:10.1111/j.1741-3737.2009.00644.x.

Weagley, R.O., Chan, M.L. \& Yan, J. (2007). Married couples' time allocation decisions and marital stability. Journal of Family and Economic Issues, 28(3), 507-525. doi:10.1007/s10834-007-9070-y.

Whitton, S.W., Rhoades, G.K., Stanley, S.M. \& Markman, H.J. (2008). Effects of parental divorce on marital commitment and confidence. Journal of Family Psychology: JFP: Journal of the Division of Family Psychology of the American Psychological Association (Division 43), 22(5), 789-793. doi:10.1037/a0012800.

Winslow, S. (2011). Marital conflict and the duration of wives' income advantage. International Journal of Sociology of the Family, 37(2), 203-225. 